\title{
Marrying research evidence and policies in Latin America and the Caribbean: the case of violence
}

\author{
Sara Ardila-Gómez ${ }^{1,2,3,4}$, David G. Lugo-Palacios ${ }^{1,5}$ and Elena Vargas-Palacios ${ }^{1}$
}

In the middle of the post-2015 development agenda, with regard to the points that relate to the health sector, a question arises within the research community on how evidence-based decisions, prioritization of problems and possible solutions are included in the global agenda (1). This concern focuses on the effectiveness of the feedback mechanisms between research and policy, and vice versa. As young Latin American researchers, we are thinking of ways to link research and policy when facing what is possibly one of the most urgent health issues in Latin America and the Caribbean (LAC): violence.

Although violence is not exclusive to LAC, the region is known to be the most violent in the world: 8 out of the 10 countries with the highest homicide rates are located in the LAC region (2). Homicide rates in LAC increased by $12 \%$ between 2000 and 2010, while decreasing in the rest of the world (3). According to the World Health Organization (WHO), interpersonal violence represented the third cause of disease burden in 2012, accounting for $4 \%$ of disability-adjusted life years (DALYs) in the region, which is higher than diabetes and stroke (4). These facts help explain why the general population considers violence and insecurity in many LAC countries a major concern, because they restrict circulation and recreational space, produce general distrust, reduce social networks and delegitimize democracy $(3,5,6)$.

The causes and consequences of violence cannot be reduced to the 'disease model'; hence, intervention strategies need to go beyond the health sector, and need to include other categories, such as suffering and resistance, which are not equivalent to disease
$(7,8)$. Violence is a health problem, but not just a health problem. This seems to have been acknowledged by some countries in the region that have developed intersectoral programs to face the violence problem, such as Colombia, El Salvador and Mexico (2,9); however, there is a lack of evidence regarding the effectiveness of most policies that have been implemented in LAC to tackle violence, which hinders the reliability of conclusions about their success (10).

In an effort to understand the link between health policies and health research in LAC, we reviewed the LILACS database, which specializes in scientific and technical literature on health in LAC, and found that it contains 3791 articles published in the last 30 years with the word violence in their titles. After analyzing the most recently published (2011-2014) articles, we identified three trends: first, the health focus is on domestic and gender-based violence research, which could be related to an increased capacity to manage the health problem in its individual and family dimensions, over the study of social and political violence; second, there is a predominance of descriptive studies, mainly at the local level; and third, there is a marginal presence of studies focusing on evaluating policies or programs to curb violence (only two from 2014). This situation could be seen as a wake-up call to change the health research agenda, in terms of trying to analyze and respond to this apparent lack of results, by putting policies themselves at the center of our research concerns: in other words, by paying more attention to implementation research.

Making this shift, which is important not just for violence, implies not only changing the research

1. Emerging Voices for Global Health 2014.

2. National Scientific and Technical Research Council of Argentina (CONICET), Argentina.

3. Department of Community Health, National University of Lanús, Argentina.

4. School of Psychology, University of Buenos Aires, Buenos Aires, Argentina.

5. London School of Hygiene and Tropical Medicine, London, UK.

Correspondence to: Sara Ardila-Gómez, Beruti 3865, Dpto. 5C, CP 1425, Buenos Aires, Argentina. Email: saraardi@ gmail.com

Global Health Promotion 1757-9759; Vol 22(1): 6-7; 566155 Copyright () The Author(s) 2015, Reprints and permissions: http://www.sagepub.co.uk/journalsPermissions.nav DOI: 10.1177/1757975914566155 http://ghp.sagepub.com 
questions but more broadly, changing the research practices. There are some aspects that need to change in order to link research and policies; for instance, whom researchers work with (not only whom the research subject is), where they work (not only where they do their fieldwork), or what their audiences and their communication channels are. There are different reasons why policy implementation research is not done in LAC. Just to mention a few, research institutions remain endogamous, that is, they privilege alliances with people inside the research and academic world, and the spread of information inside that world. There are also barriers for developing interdisciplinary research, important for violence and for health promotion at large, because academic and research institutions still work in disciplinary silos. Additionally, barring a few exceptions, the science and technology agencies in the different countries of the LAC region are still fragile, and they have oriented their limited resources to achieve global scientific standards (like publications and citations) that are still far from including implementation as an important target. Finally, and despite some changes in the last decade, LAC countries still have weak democracies, which means that there is confusion between both state and governmental policies. Due to the latter, policies and programs change based on governmental political interests, which usually have a short-term perspective.

Perhaps the first thing that needs to be changed, in order to mend the divorce between research and policy in LAC, is the mutual disdain between researchers and policy makers. As many researchers on changing prejudices and attitudes have highlighted, one way to do that is by intensifying interaction. This interaction could lead to a better understanding, not only with an attitude toward change, but also on the way research findings are communicated to other audiences, including policymakers. We find the problem is best illustrated by the researcher in The Little Prince, who in order to be heard by the scientific circle, had to learn and practice new methods: how to dress, to speak and to behave. Clearly, health promotion research seeks to be heard in political, technical and social scenarios. Just like the The Little Prince researcher, we may have to acknowledge that we need to improve the way we do research and the way we communicate it, to reach our goal.

\section{References}

1. Perkins NI. Three ways to engage science with development governance. Available from: http:// www.scidev.net/global/policy/editorials/engagescience-development-governance.html (2014, accessed 30 October 2014).

2. United Nations (UN) Office on Drugs and Crime. Global study on homicide 2013. Vienna: UN Publications; 2013.

3. United Nations Development Programme (UNPD). Citizen security with a human face: evidence and proposals for Latin America. Report for the UN, a Regional Human Development Report for 20132014. New York: UNPD; 2013.

4. World Health Organization (WHO). Health Statistics and Information System Estimates for 2002-2012 Disease Burden. Available from: www.who.int/ healthinfo/global_burden_disease/estimates/en/ index2.html (accessed 28 October 2014).

5. Corporación Latinobarómetro. Informe 2013 [2013 report]. Available from: www.latinobarometro.org/ latContents.jsp (pub year, accessed 26 October 2014).

6. Imbusch P, Misse M, Carrión F. Violence research in Latin America and the Caribbean: a literature review. Int J Conflict Crime. 2001; 5: 87-154.

7. Augsburger AC. De la epidemiología psiquiátrica a la epidemiología en salud mental: el sufrimiento psíquico como categoría clave [From psychiatric epidemiology to mental health epidemiology: psychiatric suffering as a key class]. Cuad Méd Soc. 2002; 81: 61-75.

8. Martín-Baró I. Acción e ideología: psicología social desde Centroamérica [Action and ideology: social psychology in Central America]. San Salvador: UCA Eds.; 1983.

9. De Andrade LOM, Pellegrini Filho A, Solar O, Rígoli F, De Salazar L, Castell-Florit Serrate P, et al. Social determinants of health, universal health coverage, and sustainable development: case studies from Latin American countries. Lancet. 2014; doi:10.1016/ S0140-6736(14)61494-X.

10. Buvinic M. Un balance de la violencia en América Latina: los costos y las acciones para la prevención [A balance of violence in Latin America: costs and actions to prevent it]. Pensamiento Iberoamericano. 2008; 2: 37-54. 